\title{
Optimization and characterization of vinegar produced from rice bran
}

\author{
Catiussa Maiara PAZUCH ${ }^{1}$, Daneysa Lahis KALSCHNE ${ }^{1 \star}$ (D), Francieli Begnini SIEPMANN ${ }^{1}$, \\ Itala Maria Gouveia MARX ${ }^{1}$, Tatiane Cristina Gonçalves de OLIVEIRA ${ }^{2}$, Wilma Aparecida SPINOSA², \\ Cristiane CANAN $^{1}$, Eliane COLLA ${ }^{1}$
}

\begin{abstract}
The vinegar is a millenary food, appreciated by consumers worldwide. The rice bran is a rice-processing by-product produced in a large scale, mainly employed in feed. This study describes a method for defatted rice bran (DRB) vinegar production by submerged fermentation, with optimized aeration and stirring conditions, evaluating its physico-chemical properties and acceptance. A $2^{2}$ Full Factorial Design (FFD) was applied to evaluate the aeration (0.25-1.00 VVM) and stirring (100-500 rpm) effect on the stoichiometric yield (SY), total concentration of ethanol and acetic acid yield (TCY), and acetic acid productivity (AAP). SY ranged from 26.26 to $79.97 \%$, TCY ranged from 78.04 to $100.50 \%$, and AAP varied from 0.056 to $0.473 \mathrm{~g} \mathrm{~L}^{-1} \mathrm{~h}^{-1}$. The stirring had a positive effect in the SY and TCY, while both aeration and stirring had a positive effect in the AAP ( $\mathrm{p} \leq 0.05)$. The FFD allowed an acetic acid increase of $\cong 750$ times under aeration of $1.00 \mathrm{VVM}$ and stirring of $500 \mathrm{rpm}$, which made it possible to develop an industrially compatible method for vinegar production using DRB as substrate. Furthermore, DRB presents potential for vinegar production, with functional characteristics - including antioxidant activity - and sensorially accepted.
\end{abstract}

Keywords: antioxidant activity; defatted rice bran; fermentation; full factorial design; phytic acid.

Practical Application: Vinegar production from rice bran by submerged fermentation.

\section{Introduction}

Vinegar is a millenary food, appreciated by its consumers specially associated with salads, but also applied in a wide variety of products (Ho et al., 2017). In Brazil, the vinegar consumption reach 170 million $\mathrm{L}$ per year and $80 \%$ refers to ethanol vinegar. According to National Association of Vinegar Industries, the Brazilian consumption is $0.8 \mathrm{~L}$ per capita, while in Europe and USA the consumption reach $1.8 \mathrm{~L}$ per capita (Associação Nacional das Indústrias de Vinagre, 2019). The vinegar production occurs by two biochemical processes: the alcoholic fermentation of sugars/starches by the action of yeasts, usually Saccharomyces species, followed by acetic fermentation of ethanol by aerobic acetic bacteria (Araújo et al., 2012; Marques et al., 2010).

Vinegar has been used medicinally in order to treat diseases for long the centuries, including healing of wounds, poison ivy, croup, stomachache, high fever, edema, infections, ulcerations, and others (Ho et al., 2017). More recently, the presence of bioactives in vinegar and its mechanisms of action in health have been investigated. In this context, the regular consumption of vinegar contributes to some beneficial effects in digestion, appetite stimulation, antiobesity, antitumor, antioxidative, antimicrobial, recovery from exhaustion, lipid content, cardiovascular disease, regulating blood pressure, antidiabetic and therapeutic properties (Budak et al., 2014; Chou et al., 2015; Ho et al., 2017).

Rice cultivation is essential for food and nutritional safe for more than half the population worldwide, besides being part of the food habit of the Brazilian population. Brazil is the largest producer of rice (Oryza sativa) outside Asia and, the 2018/2019 rice crop should reaches a productivity of 10653.8 thousand tons (Companhia Nacional de Abastecimento, 2019). The preference of Brazilian rice consumers involves the white rice $(70 \%)$, parboiled (25\%), and whole grain (3-4\%) (Companhia Nacional de Abastecimento, 2015). For white rice obtaining, the whole grain is subjected to the peeling process followed by polishing and the by-product of polishing is the rice bran, composed by pericarp, aleurone and germ (Canan et al., 2011). The rice bran represents 8 to $11 \%$ of the total grain weight and, in Brazil, is mainly employed in the animal feed (Gomes et al., 2012).

The rice bran present high content of carbohydrates (52\%), starch (15\%), fat (21\%), and protein (15\%) (Amagliani et al., 2017). The higher carbohydrate content justifying the use of rice bran in fermentative processes as vinegar production; although, the protein and lipid content may harm yeast's performance on ethanol production (Watanabe et al., 2009). The defatted rice bran (DRB), with lower fat $(<2 \%)$ and higher carbohydrates $(60 \%)$ and starch (21\%) content (Watanabe et al., 2019), if submitted to hydrolysis, is a potential substrate for vinegar production. In this context, the aim of this study was to propose a method for DRB vinegar production by submerged fermentation. The aeration and stirring conditions were evaluated by a full factorial design (FFD) regarding the yield and productivity. 
Moreover, the vinegar produced was characterized regarding physico-chemical parameters and acceptance.

\section{Materials and methods}

The DRB (lipid 1.88\%; ash $12.72 \%$; protein $16.75 \%$; carbohydrate $68.65 \%$; phytic acid $6.65 \%$ ) was provided by the Riograndense Vegetable Oils Company (Pelotas, Brazil). The enzymes protease (Alcalase 2.4L FG), $\alpha$-amylase (Termamyl 2X), and amyloglucosidase (AMG 300L) used in the enzymatic hydrolysis were provided by the Latin American LNF (Bento Gonçalves, Brazil). Acetozyn ${ }^{\circledR}$, a mixture of inorganic salts, sugars, plant extracts, amino acids, and vitamins that provide the nutrients for acetic bacteria, was provided by Frings (Piracicaba, Brazil). Freeze-dried S. cerevisiae yeast $\left(\right.$ Saf-instant $\left.{ }^{\circledR}\right)$ was used in alcoholic fermentation. The acetic fermentation was performed by acetic bacteria from undiluted alcohol vinegar ( $\cong 8 \%$ acidity; $\mathrm{w} / \mathrm{v}$ ) from an earlier fermentation (strong vinegar) provided by Chemim (Ponta Grossa, Brazil). This inoculum was composed by Acetobacter, Gluconobacter and Komagataeibacter, used in vinegar production due its ability to oxidize ethanol to acetic acid and high resistance to acetic acid released during fermentation (Gomes et al., 2018).

\subsection{Vinegar production}

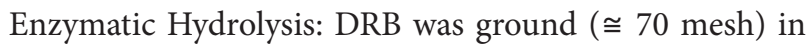
a knife mill (SL 31, Solab, Piracicaba, Brazil) and hydrolysed as previously described by Siepmann et al. (2018) in order to release fermentable sugars. The following enzymatic hydrolysis was conducted in a DRB suspension $\left(200 \mathrm{~g} \mathrm{~L}^{-1}\right)$ : protease $\left(15 \mu \mathrm{L} \mathrm{g}^{-1} \mathrm{DRB}\right)$ kept at $60^{\circ} \mathrm{C}$ for $2 \mathrm{~h}$; $\alpha$-amylase $\left(30 \mu \mathrm{L} \mathrm{g}^{-1} \mathrm{DRB}\right)$ kept at $90-95^{\circ} \mathrm{C}$ for $2 \mathrm{~h}$; and amyloglucosidase $\left(40 \mu \mathrm{L} \mathrm{g}^{-1} \mathrm{DRB}\right)$ kept at $55-60^{\circ} \mathrm{C}$ for $3 \mathrm{~h}$. After hydrolysed, the DRB suspension was centrifuged for $5 \mathrm{~min}$ at $3823 \mathrm{~g}$ (Rotina 420R, Hettich, Spenge, Germany) and the supernatant were used for vinegar elaboration.

Alcoholic Fermentation: the DRB hydrolysed (1.5 L; $\mathrm{pH}$ 5.0) was inoculated with Saccharomyces cerevisiae in the proportion of $5.0 \%(\mathrm{w} / \mathrm{v})$. The alcoholic fermentation was carried out in $3 \mathrm{~L}$ erlenmeyer disposed an incubator (SL 221, Solab, Brazil) at $30^{\circ} \mathrm{C}$ for $48 \mathrm{~h}$ at a stationary state. Subsequently, the wine (alcoholic fermentation product) was centrifuged for $3 \mathrm{~min}$ at $3823 \mathrm{~g}$ (yeast cells separation) to be used in acetic fermentation.

Acetic Fermentation: the wine ethanol percentage $(3.6 \%(\mathrm{v} / \mathrm{v}))$ was corrected to $5 \%$, as recommended for ethanol initial concentration in wine (Aquarone et al., 2001), by the addition of commercial ethanol $(70 \% \mathrm{v} / \mathrm{v}$, Da Ilha, Almirante Tamandaré, Brazil). The strong vinegar was initially diluted in wine in the proportion of $10 \%(\mathrm{v} / \mathrm{v})$ in order to adapt the acetic bacteria in the medium. Further, the wine (ethanol: $5.0 \pm 0.23 \%$; acidity: $0.9 \pm 0.03 \%$; v/v) was inoculated with the diluted strong vinegar (ethanol: $2.1 \pm 0.15 \%$; acidity: $8.9 \pm 0.04 \% ; \mathrm{v} / \mathrm{v}$ ) in the proportion of 1.5:1.0. Subsequently, the syrup was added of $1 \mathrm{~g} \mathrm{~L}^{-1}$ of Acetozyn ${ }^{\circledR}$. The final syrup was submitted to the acetic fermentation in a benchtop fermentor (Bioreactor Tec-Bio 7.5 L, Tecnal, Piracicaba,
Brazil). The process conditions were set at $30^{\circ} \mathrm{C}, 0.25 \mathrm{VVM}$ aeration (air volume $\mathrm{x}$ must volume $\mathrm{e}^{-1} \mathrm{x}$ minute ${ }^{-1}$ ) and stirring at $300 \mathrm{rpm}$. The final of acetic fermentation was achieved when ethanol reached levels between 1.0 and $0.5 \%(\mathrm{v} / \mathrm{v})$ (Brasil, 2012); at this stage, $1 / 8$ of the vinegar volume was removed and the wine was added in the same ratio, characterizing a semi-continuous process. Eleven fermentation cycles (syrup exchanges) was performed to activate and stabilizer the acetic bacteria for further FFD.

The monitoring of acetic fermentation was performed by acid and ethanol determination, removing aliquots from the fermented syrup at 8 -h intervals. The stoichiometric yield (SY) was calculated according to Spinosa et al. (2015), considering that $1.0 \mathrm{~g}$ ethanol yield $1.304 \mathrm{~g}$ acetic acid. The total concentration of ethanol and acetic acid yield (TCY) and the acetic acid productivity (AAP) were calculated by Equation 1 (Spinosa et al., 2015) and Equation 2 (Ferreyra et al., 2012), respectively.

$$
\begin{gathered}
T C Y=\frac{\text { Final etanhol concentration }(\%)+\text { Final acidity concentration }(\%)}{\text { Initial ethanol concentration }(\%)+\text { Initial acidity concentration }(\%)} \\
A A P=\frac{\text { Acetic acid concentration on time } e_{2} \text {-Acetic acid concentration on time } e_{1}}{\text { time }_{2}-\text { time }_{1}}
\end{gathered}
$$

From the $12^{\text {th }}$ fermentation cycle to each new cycle was carried out an experimental run of an FFD. The wine was adjusted to $6 \%(\mathrm{v} / \mathrm{v})$ by the commercial alcohol addition, since the acidity was decreasing excessively, which could cause the fermentation medium contamination.

The FFD $2^{2}$ evaluate the effects of variables aeration (0.25-1.00 VVM) and stirring (300-500 rpm) considering the responses SY and TCY. The vinegar obtained was clarified with bentonite $(2 \%$ w $/ \mathrm{v})$ for $48 \mathrm{~h}$, vacuum filtrated and pasteurized at $65^{\circ} \mathrm{C}$ for $30 \mathrm{~min}$. All runs were randomly conducted and the results were analyzed using the Statistica 7.0 software (Statsoft Inc., Tulsa, OK, USA). The models' adequacy was evaluated by Anova $(\mathrm{p} \leq 0.05)$.

\subsection{Vinegar characterization and acceptance}

The vinegar produced using $0.25 \mathrm{VVM}$ of aeration and $100 \mathrm{rpm}$ of stirring was characterized regarding alcohol content (969.12, Association of Official Analytical Chemists, 2012), total acidity (930.35, Association of Official Analytical Chemists, 2012), reduced dry extract, ash (Brasil, 2012), and phytic acid content (Canan et al., 2011). The antioxidant activity was determined by the electron donating capacity of the vinegar to the stable free radical DPPH (Blois, 1958; Sánchez-Moreno, 2002). The sensory analysis was approved by the Ethics Committee of Universidade Tecnológica Federal do Paraná (CAAE: 35679914.6.0000.5547). The acceptance of vinegar was evaluated by 112 assessors (consumers) in individual booths with white lighting. The sample $(\cong 10 \mathrm{~mL})$ was served at $25-30{ }^{\circ} \mathrm{C}$ in white plastic cup codified with 3 random digits to poured over lettuce by the assessor. The attributes of color, aroma, viscosity, flavor and overall impression were evaluated thought 9 -point hedonic scale $(1=$ disliked extremely, $5=$ neither liked, nor disliked, $9=$ like extremely). 


\section{Results and discussion}

The DRB hydrolysed presented $61.23 \pm 0.03 \mathrm{~g} \mathrm{~L}^{-1}$ of reducing sugars and the wine obtained yielded $3.62 \pm 0.23 \%(\mathrm{v} / \mathrm{v})$ of ethanol. These values was lower than that described by (Siepmann et al., 2018), which optimized the DRB hydrolysis process and obtained $68.8 \mathrm{~g} \mathrm{~L}^{-1}$ of reducing sugar and $4.0 \%(\mathrm{v} / \mathrm{v})$ of ethanol. The different values of reducing sugar could be associated with the variations in the raw material composition and it may affect the final ethanol content. Thus, in order to initiate the acetic fermentation, the wine's alcohol content was corrected to $5.0 \%(\mathrm{v} / \mathrm{v})$ with commercial ethanol.

Table 1 shows the SY for the eleven fermentative cycles, with a mean $(23.7 \%)$ considered low because, in industrial terms, the yield is economically viable if reaches $\cong 76 \%$ (Aquarone \& Zancanaro, 1983). The highest SY (52.43\%) and the lowest fermentation time $(29 \mathrm{~h})$ was observed for cycle 2 . The long-time interval of cycle 1 could be explained by problems with oxygen supply failure. The cycle during from 29 to $128 \mathrm{~h}$ presented a high process variation; however, except cycle 1 and 11, time average was $44.33 \mathrm{~h}$. The cycle interval was greater than that described in the literature (18-30 h) and intervals between each change of syrup greater than $30 \mathrm{~h}$ might be related to cycles' instability (Macías et al., 1997). Furthermore, the inoculum from strong alcohol vinegar may justify the low SY obtained, considering that the bacteria was transferred to a substrate with different characteristics, requiring longer adaptation time and presented greater lag phase. Moreover, the acetic bacteria are strictly aerobic and its metabolism was altered when transferred from a high oxygen medium to a little-dissolved oxygen. Summarizing, the fermentation interval depends mainly on the initial ethanol concentration, the aeration efficiency, and the bacterial lag phase; however, the oxygen supply failure in the cycle 1 and the conditions used in the study - aeration and stirring - must be taken into account.

The TCY and AAP for the eleven fermentative cycles ranged from 74.21 to $97.60 \%$ and from 0.031 to $0.097 \mathrm{~g} \mathrm{~L}^{-1} \mathrm{~h}^{-1}$ (with an average value of $0.063 \pm 0.02 \mathrm{~g} \mathrm{~L}^{-1} \mathrm{~h}^{-1}$ ), respectively (Table 1). In comparison, Spinosa et al. (2015) reported TCY from 80.6 to $105.9 \%$ for rice vinegar, representing, in general, slightly higher values than the present study. The same authors also reported a higher AAP, from 0.140 to $0.881 \mathrm{~L}^{-1} \mathrm{~h}^{-1}$. Similarly, the productivity for other substrates were higher than the present study; Silva et al. (2007) obtained an AAP of $0.55 \mathrm{~g} \mathrm{~L}^{-1} \mathrm{~h}^{-1}$ for cashew vinegar, Bortolini et al. (2001), comparing the submerged and generator processes, obtained an AAP of 0.29 and $1.73 \mathrm{~g} \mathrm{~L}^{-1} \mathrm{~h}^{-1}$, respectively.

\subsection{Optimization of acetic fermentation stage}

The responses for DRB vinegar yields and productivity of FFD were present in Table 2. The SY ranged from 26.26 to $79.97 \%$ and the TCY ranged from 78.04 to $100.50 \%$. For both responses, the curvature and stirring shows a negative and positive effect, respectively ( $\mathrm{p} \leq 0.05)$ (Table 3$)$. Thus, at the higher stirring condition (500 rpm) an increase in SY and TCY was observed. The non-significant effect of $\mathrm{x}_{1}$ and $\mathrm{x}_{1}$ by $\mathrm{x}_{2}$ was incorporated into the residue of the model, and a valid linear model was obtained for SY $\left(\mathrm{F}_{\text {calculated }}: 13.69 ; \mathrm{F}_{\text {tabulated }}: 6.94 ; \mathrm{p}\right.$-value: 0.016 ;

Table 1. Parameters of wines from the eleven fermentative cycles.

\begin{tabular}{|c|c|c|c|c|c|c|c|c|}
\hline Cycle & $\begin{array}{l}\text { Time } \\
\text { (h) }\end{array}$ & $\begin{array}{l}\text { Ethanol } \\
(\% ; \mathrm{v} / \mathrm{v})\end{array}$ & $\begin{array}{l}\text { Acetic acid } \\
(\% ; \mathrm{w} / \mathrm{v})\end{array}$ & $\begin{array}{c}\text { Theoretical } \\
\text { acetic } \\
\text { acid }(\% ; \mathrm{w} / \mathrm{v})\end{array}$ & $\begin{array}{l}\text { SY } \\
(\%)\end{array}$ & $\begin{array}{l}\mathrm{TC} \\
(\%)\end{array}$ & $\begin{array}{l}\text { TCY } \\
(\%)\end{array}$ & $\begin{array}{c}\text { AAP } \\
\left(\mathrm{g} \mathrm{L}^{-1} \mathrm{~h}^{-1}\right)\end{array}$ \\
\hline \multirow[t]{2}{*}{1} & 0 & $1.87 \pm 0.03$ & $5.42 \pm 0.03$ & - & - & 7.29 & - & \\
\hline & 128 & $0.54 \pm 0.06$ & $5.82 \pm 0.00$ & 1.73 & $23.13 \pm 2.75$ & 6.36 & $87.25 \pm 1.05$ & $0.031 \pm 0.003$ \\
\hline \multirow[t]{2}{*}{2} & 0 & $1.17 \pm 0.05$ & $4.54 \pm 0.03$ & - & - & 5.71 & - & \\
\hline & 29 & $0.73 \pm 0.06$ & $4.82 \pm 0.03$ & 0.57 & $52.43 \pm 7.73$ & 5.01 & $97.60 \pm 0.67$ & $0.097 \pm 0.016$ \\
\hline \multirow[t]{2}{*}{3} & 0 & $1.69 \pm 0.10$ & $3.78 \pm 0.06$ & - & - & 5.47 & - & \\
\hline & 42 & $0.53 \pm 0.03$ & $4.06 \pm 0.03$ & 1.51 & $18.51 \pm 3.87$ & 4.59 & $84.01 \pm 2.39$ & $0.067 \pm 0.011$ \\
\hline \multirow[t]{2}{*}{4} & 0 & $1.46 \pm 0.08$ & $3.50 \pm 0.03$ & - & - & 4.96 & - & \\
\hline & 48 & $0.47 \pm 0.04$ & $3.74 \pm 0.03$ & 1.29 & $18.92 \pm 2.93$ & 4.21 & $84.85 \pm 4.00$ & $0.050 \pm 0.000$ \\
\hline \multirow[t]{2}{*}{5} & 0 & $1.65 \pm 0.21$ & $3.20 \pm 0.03$ & - & - & 4.85 & - & \\
\hline & 59 & $0.45 \pm 0.10$ & $3.56 \pm 0.03$ & 1.56 & $23.14 \pm 2.17$ & 4.01 & $82.72 \pm 1.45$ & $0.061 \pm 0.000$ \\
\hline \multirow[t]{2}{*}{6} & 0 & $1.44 \pm 0.13$ & $3.24 \pm 0.00$ & - & - & 4.68 & - & \\
\hline & 58 & $0.56 \pm 0.10$ & $3.42 \pm 0.00$ & 1.14 & $15.78 \pm 0.90$ & 3.98 & $85.11 \pm 0.84$ & $0.031 \pm 0.000$ \\
\hline \multirow[t]{2}{*}{7} & 0 & $1.91 \pm 0.10$ & $2.96 \pm 0.03$ & - & - & 4.87 & - & \\
\hline & 51 & $0.55 \pm 0.06$ & $3.30 \pm 0.00$ & 1.77 & $19.24 \pm 2.63$ & 3.85 & $79.08 \pm 1.47$ & $0.067 \pm 0.007$ \\
\hline \multirow[t]{2}{*}{8} & 0 & $1.67 \pm 0.08$ & $2.82 \pm 0.00$ & - & - & 4.49 & - & \\
\hline & 37 & $0.53 \pm 0.10$ & $3.12 \pm 0.00$ & 1.49 & $20.29 \pm 1.77$ & 3.65 & $81.25 \pm 2.57$ & $0.081 \pm 0.000$ \\
\hline \multirow[t]{2}{*}{9} & 0 & $1.65 \pm 0.08$ & $2.58 \pm 0.00$ & - & - & 4.23 & - & \\
\hline & 34 & $0.68 \pm 0.13$ & $2.90 \pm 0.03$ & 1.26 & $25.49 \pm 2.59$ & 3.58 & $84.76 \pm 1.46$ & $0.094 \pm 0.010$ \\
\hline \multirow[t]{2}{*}{10} & 0 & $1.22 \pm 0.08$ & $2.58 \pm 0.00$ & - & - & 3.80 & - & \\
\hline & 41 & $0.54 \pm 0.03$ & $2.78 \pm 0.03$ & 0.89 & $20.18 \pm 1.55$ & 3.32 & $87.23 \pm 2.00$ & $0.049 \pm 0.008$ \\
\hline \multirow[t]{2}{*}{11} & 0 & $2.10 \pm 0.08$ & $2.54 \pm 0.03$ & - & - & 4.64 & - & \\
\hline & 88 & $0.35 \pm 0.07$ & $3.10 \pm 0.03$ & 2.29 & $24.45 \pm 1.44$ & 3.45 & $74.21 \pm 1.96$ & $0.064 \pm 0.004$ \\
\hline
\end{tabular}

SY: stoichiometric yield; TC: total concentration; TCY: total concentration yield; AAP: acetic acid productivity. 
Table 2. FFD matrix with codified and real variables and responses.

\begin{tabular}{cccccc}
\hline Run & $\mathrm{x}_{1}-$ aeration $(\mathrm{VVM})$ & $\mathrm{x}_{2}-$ stirring $(\mathrm{rpm})$ & $\mathrm{SY}(\%)$ & TCY $(\%)$ & $\left.\mathrm{AAP}(\mathrm{g} \mathrm{L})^{-1} \mathrm{~h}^{-1}\right)$ \\
\hline 1 & $-1(0.25)$ & $-1(100)$ & $26.41 \pm 1.89$ & $85.04 \pm 1.75$ & $0.056 \pm 0.005$ \\
2 & $+1(1.00)$ & $-1(100)$ & $38.81 \pm 2.64$ & $88.62 \pm 2.68$ & $0.326 \pm 0.018$ \\
3 & $-1(0.25)$ & $+1(500)$ & $64.98 \pm 3.87$ & $96.02 \pm 1.42$ & $0.455 \pm 0.031$ \\
4 & $+1(1.00)$ & $+1(500)$ & $79.97 \pm 7.97$ & $100.50 \pm 1.27$ & $0.473 \pm 0.031$ \\
5 & $0(0.63)$ & $0(300)$ & $26.74 \pm 3.28$ & $84.15 \pm 2.01$ & $0.144 \pm 0.000$ \\
6 & $0(0.63)$ & $0(300)$ & $26.26 \pm 1.02$ & $78.04 \pm 0.80$ & $0.142 \pm 0.014$ \\
7 & $0(0.63)$ & $0(300)$ & $41.66 \pm 2.08$ & $87.59 \pm 1.64$ & $0.177 \pm 0.010$ \\
\hline
\end{tabular}

SY: stoichiometric yield; TCY: total concentration yield; AAP: acetic acid productivity.

Table 3. Effects of FFD variables aeration and stirring on responses.

\begin{tabular}{|c|c|c|c|c|c|c|c|c|c|c|c|c|}
\hline & Effect & SD & $\mathrm{t}(2)$ & $\mathrm{p}$-value & Effect & SD & $\mathrm{t}(2)$ & $\mathrm{p}$-value & Effect & SD & $\mathrm{t}(2)$ & $\mathrm{p}$-value \\
\hline & \multicolumn{4}{|c|}{ SY (\%) } & \multicolumn{4}{|c|}{ TCY (\%) } & \multicolumn{4}{|c|}{$\operatorname{AAP}\left(\mathrm{g} \mathrm{L}^{-1} \mathrm{~h}^{-1}\right)$} \\
\hline Average & 52.54 & 4.63 & 11.36 & $0.000^{*}$ & 92.55 & 1.99 & 46.55 & $0.000^{*}$ & 0.33 & 0.01 & 33.32 & $0.001^{*}$ \\
\hline $\mathrm{C}$ & -41.98 & 14.14 & -2.97 & $0.041^{\star}$ & -18.57 & 6.07 & -3.06 & $0.038^{*}$ & -0.35 & 0.03 & -11.54 & $0.007^{\star}$ \\
\hline $\mathrm{x}_{1}$ & - & - & - & - & - & - & - & - & 0.14 & 0.02 & 7.33 & $0.018^{\star}$ \\
\hline $\mathrm{x}_{2}$ & 39.87 & 9.25 & 4.31 & $0.013^{*}$ & 11.43 & 3.98 & 2.87 & $0.045^{\star}$ & 0.27 & 0.02 & 13.89 & $0.005^{\star}$ \\
\hline $\mathrm{x}_{1}$ by $\mathrm{x}_{2}$ & - & - & - & - & - & - & - & - & -0.13 & 0.02 & -6.41 & $0.023^{*}$ \\
\hline
\end{tabular}

SD: standard deviation; SY: stoichiometric yield; TCY: total concentration yield; AAP: acetic acid productivity; $\mathrm{C}$ : curvature $\left(\mathrm{C}=1\right.$ on central point, for $\mathrm{x}_{1}$ and $\mathrm{x}_{2}=0$; $\mathrm{C}=0$ on the other points); $\mathrm{x}_{1:}$ aeration $(\mathrm{VVM}) ; \mathrm{x}_{2:}$ stirring (rpm); ${ }^{*} \mathrm{p} \leq 0.05$.
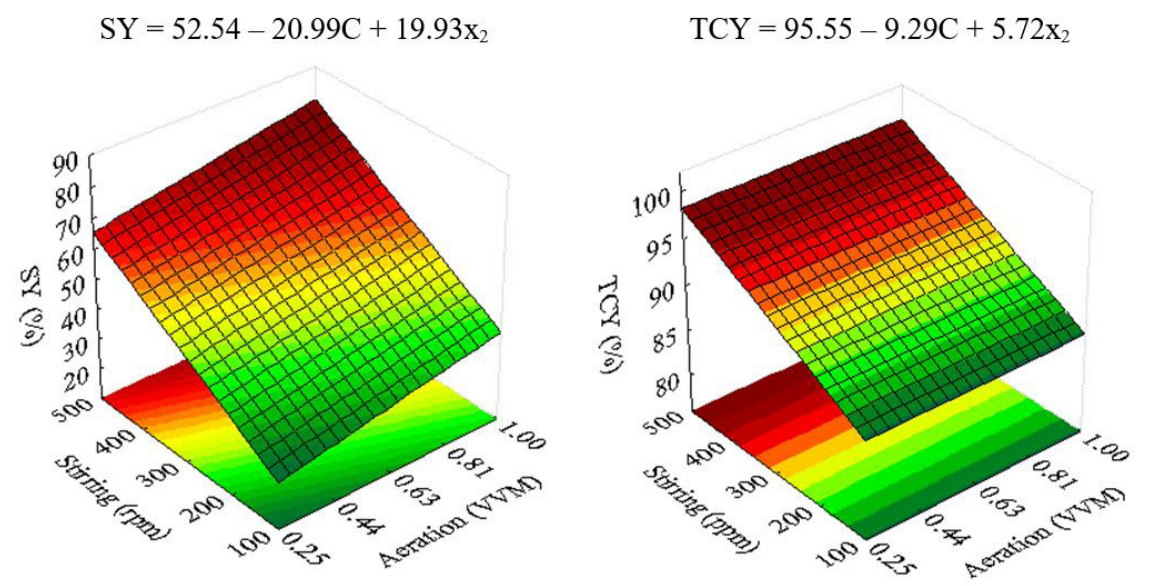

$$
\mathrm{AAP}=0.33-0.17 \mathrm{C}+0.07 \mathrm{x}_{1}+0.14 \mathrm{x}_{2}-0.06 \mathrm{x}_{1} \mathrm{x}_{2}
$$

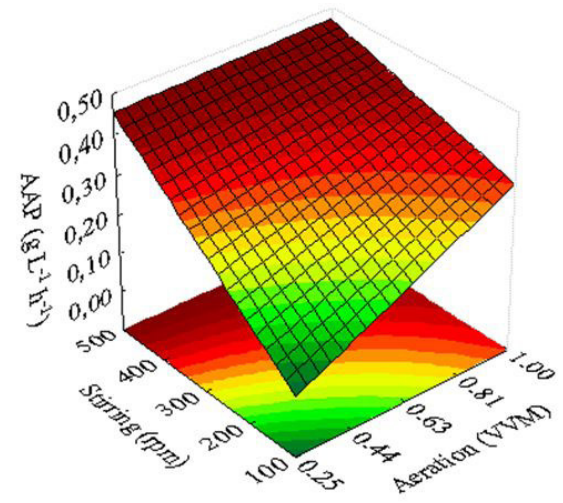

Figure 1. Surface response of stoichiometric yield (SY), total concentration yield (TCY) and acetic acid productivity (AAP).

$\mathrm{R}^{2}: 0.87 ;$ Adjusted $\left.\mathrm{R}^{2}: 0.81\right)$ and TCY $\left(\mathrm{F}_{\text {calculated }}: 8.81 ; \mathrm{F}_{\text {tabulated }}: 6.94\right.$; p-value: $0.034 ; \mathrm{R}^{2}: 0.81 ;$ Adjusted $\left.\mathrm{R}^{2}: 0.72\right)$ and the surface response was presented in Figure 1. In the present study, the highest values of SY and TCY (run 3 and 4) coincided with higher stirring rate. According to Doran (1998), an increase in stirring improves the volumetric oxygen transfer coefficient ( $\mathrm{kLa})$ value under typical fermenter conditions, whereas an increase in aeration does not cause a similar effect on this coefficient. Moreover, acetic bacteria are a strictly aerobic microorganism, thus a constant oxygen supply is required throughout the process. On the other hand, an oversupply of oxygen could affect volatile components in the substrate, such ethanol, and may reduce the quality and yield of the final product (Tesfaye et al., 2003).
For AAP, values from 0.051 to $0.473 \mathrm{~g} \mathrm{~L}^{-1} \mathrm{~h}^{-1}$ were observed for FFD runs (Table 2 ). The aeration and stirring had a positive effect in $\operatorname{AAP}(\mathrm{p} \leq 0.05)$, while the curvature and $\mathrm{x}_{1}$ by $\mathrm{x}_{2}$ had a negative effect in the same response $(\mathrm{p} \leq 0.05)$. Thus, at the higher aeration $(1.00 \mathrm{VVM})$ and stirring condition (500 rpm) an increase in AAP was observed. A valid linear model was obtained for $\operatorname{AAR}\left(\mathrm{F}_{\text {calculated }}: 105.19 ; \mathrm{F}_{\text {tabulated }}\right.$ : 19.25; p-value: 0.009; $R^{2}$ : 0.99; Adjusted $\left.R^{2}: 0.99\right)$ and the surface response was presented in Figure 1. Comparing the productivity of run $4\left(0.473 \mathrm{~g} \mathrm{~L}^{-1} \mathrm{~h}^{-1}\right)$ with the eleven fermentation cycles mean $\left(0.063 \mathrm{~g} \mathrm{~L}^{-1} \mathrm{~h}^{-1}\right)$, the experimental design may improve the AAP by $\cong 750$ times, emphasizing the relevance of fermentative substrate aeration and stirring. In his context, run 4 was considered the best condition in order to improve the DRB acetic acid production by alcoholic fermentation. 


\subsection{Vinegar characterization and acceptance}

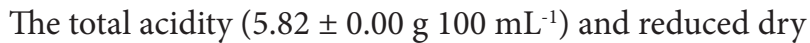
extract $\left(35.66 \pm 3.81 \mathrm{~g} \mathrm{~L}^{-1}\right)$ obtained was in accordance with the Brazilian legislation parameter of a minimum of $4 \mathrm{~g} 100 \mathrm{~mL}^{-1}$ and minimum of $7.00 \mathrm{~g} \mathrm{~L}^{-1}$, respectively (Brasil, 2012). In contrast, the vinegar produced surpassed $\left(7.55 \pm 0.37 \mathrm{~g} \mathrm{~L}^{-1}\right)$ the ash level required by legislation (1.00 to $4.00 \mathrm{~g} \mathrm{~L}^{-1}$ ) (Brasil, 2012). It is important to emphasize that rice bran is a by-product of the rice industry, characterized by a high ash content since it is composed by the pericarp, aleurone and germ (Canan et al. 2011). The DRB ash content of $12.72 \%$ implies in the higher ash content of vinegar. However, the legislation parameter of vinegar from cereal do not consider specific substrates which may be a mineral source as rice bran, with mineral content between 7.76 and 7.63\%; the main mineral present in rice bran are $\mathrm{P}, \mathrm{K}$ and $\mathrm{Mg}$ and, to a lesser extent, Ca, Mn, Fe, and Zn (Lacerda et al., 2010). Regarding acidity, Marques et al., (2010) noted that orange-honey (5.14 $\left.\mathrm{g} \mathrm{L}^{-1}\right)$, orange $\left(3.65 \mathrm{~g} \mathrm{~L}^{-1}\right)$, tangerine-corn $\left(3.46 \mathrm{~g} \mathrm{~L}^{-1}\right)$, and rice $\left(3.75 \mathrm{~g} \mathrm{~L}^{-1}\right)$ vinegars presented higher ash contents when compared to sugar cane $\left(0.82 \mathrm{~g} \mathrm{~L}^{-1}\right)$, sugar cane-corn $\left(0.99 \mathrm{~g} \mathrm{~L}^{-1}\right)$, red and white wine conventional vinegars (1.49 and $\left.0.72 \mathrm{~g} \mathrm{~L}^{-1}\right)$. Thus, the substrate presents a greater influence in the vinegar ash content.

The phytic acid content of vinegar produced was $2.29 \pm 0.02 \mathrm{~g} \mathrm{~L}^{-1}$. The DRB was considered a source of phytic acid

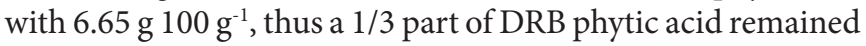
in the vinegar after acetic fermentation. Phytic acid is a natural antioxidant found in plants; its antioxidant activity has already been reported in several studies (Kim \& Lim 2016; Rodrigues et al. 2019). According to the DPPH analysis, DRB vinegar presented $10.62 \pm 1.02 \mu \mathrm{g} \mathrm{mL}^{-1} \mathrm{EC}_{50}$, a satisfactory result when compared with kurosu $\left(1710 \mu \mathrm{g} \mathrm{mL}^{-1} \mathrm{EC}_{50}\right)$ - a wholegrain rice vinegar containing rice bran - and polished rice vinegar $\left(3340 \mu \mathrm{g} \mathrm{mL}^{-1} \mathrm{EC}_{50}\right)$ (Shimoji et al., 2002). Nishidai et al. (2000) evaluated kurosu, rice, grain, apple, and grape vinegar regarding DPPH antioxidant activity; kurosu and apple vinegar extract presented the best radical antioxidant activity, 154 and $288 \mu \mathrm{g} \mathrm{mL}^{-1} \mathrm{EC}_{50}$, respectively, while the results for rice and grape vinegar were higher than $500 \mu \mathrm{g} \mathrm{mL}^{-1} \mathrm{EC}_{50}$, showing low antioxidant activity.

The sensory test indicated the acceptance of vinegar produced. The attributes of color, aroma, viscosity, flavor and overall impression had sensory means of $6.34 \pm 1.93,6.81 \pm 1.57$, $5.41 \pm 2.24,5.30 \pm 2.36$ and 5.74 \pm 2.21 , respectively. Araújo et al. (2012) reported sensory means for color (6.36 to 6.68) and aroma (6.24 to 6.60) acceptance of lime orange vinegar near the values obtained in the present study, using the 9-point hedonic scale.

\section{Conclusions}

It was possible to develop a method for vinegar production using DRB as substrate by submerged fermentation. Optimized aeration $(1.00 \mathrm{VVM})$ and stirring $(500 \mathrm{rpm})$ conditions were achieved during the fermentation process, for maximum yield and productivity. The method developed are compatible with industrial manufacturing processes of vinegar production, do not imply industrial plants modifications and avoiding extra costs. Furthermore, the DRB is a by-product with great potential for vinegar production, generating a final product with functional characteristics, including antioxidant activity, and sensorially accepted.

\section{Acknowledgements}

This study was financed in part by the Coordenação de Aperfeiçoamento de Pessoal de Nível Superior - Brasil (CAPES) - Finance Code 001 and Fundação Araucária (scholarship).

\section{References}

Amagliani, L., O’Regan, J., Kelly, A. L., \& O’Mahony, J. A. (2017). Composition and protein profile analysis of rice protein ingredients. Journal of Food Composition and Analysis, 59, 18-26. http://dx.doi. org/10.1016/j.jfca.2016.12.026.

Aquarone, E., \& Zancanaro, O. Jr. (1983). Vinagres. In E. Aquarone, U. A. Lima, \& W. Borzani (Eds.), Alimentos e bebidas produzidos por fermentação. São Paulo: Bluscher.

Aquarone, E., Borzani, W., Schmidell, W., \& Lima, V. A. (2001). Biotecnologia industrial: biotecnologia na produção de alimentos. São Paulo: Blucher.

Araújo, L. T., Silva, C. E. F., \& Abud, A. K. S. (2012). Produção de vinagre de laranja 'Lima' em vinagreira artesanal. Scientia Plena, 8(12), 1-7.

Associação Nacional das Indústrias de Vinagre - ANAV. (2019). Os tipos de vinagres. Retrieved from http://www.anav.com.br/ clipping_interna.php?id=26

Association of Official Analytical Chemists - AOAC. (2012). Official methods of analysis of the Association of Official Analytical Chemists (19th ed.). Gaitherburg: AOAC International.

Blois, M. S. (1958). Antioxidant determinations by the use of a stable free radical. Nature, 181(4617), 1199-1200. http://dx.doi. org/10.1038/1811199a0.

Bortolini, F., Sant'Anna, E. S., \& Torres, R. C. (2001). Comportamento das fermentações alcoólica e acética de sucos de kiwi (Actinidia deliciosa); composição dos mostos e métodos de fermentação acética. Food Science and Technology (Campinas), 21(2), 236-243. http://dx.doi.org/10.1590/S0101-20612001000200020.

Brasil. Ministério da Agricultura, Pecuária e Abastecimento. (2012 April 4). Instrução Normativa n. 6, de 3 de abril de 2012. Diário Oficial [da] República Federativa do Brasil, seção 1. Retrieved from http://www.agricultura.gov.br/assuntos/inspecao/produtos-vegetal/ legislacao-1/biblioteca-de-normas-vinhos-e-bebidas/instrucaonormativa-no-6-de-3-de-abril-de-2012.pdf/view

Budak, N. H., Aykin, E., Seydim, A. C., Greene, A. K., \& Guzel-Seydim, Z. B. (2014). Functional properties of vinegar. Journal of Food Science, 79(5), R757-R764. http://dx.doi.org/10.1111/1750-3841.12434. PMid:24811350.

Canan, C., Cruz, F. T. L., Delaroza, F., Casagrande, R., Sarmento, C. P. M., Shimokomaki, M., \& Ida, E. I. (2011). Studies on the extraction and purification of phytic acid from rice bran. Journal of Food Composition and Analysis, 24(7), 1057-1063. http://dx.doi. org/10.1016/j.jfca.2010.12.014.

Chou, C. H., Liu, C. W., Yang, D. J., Wu, Y. H. S., \& Chen, Y. C. (2015). Amino acid, mineral, and polyphenolic profiles of black vinegar, and its lipid lowering and antioxidant effects in vivo. Food Chemistry, 168, 63-69. http://dx.doi.org/10.1016/j.foodchem.2014.07.035. PMid:25172684. 
Companhia Nacional de Abastecimento - CONAB. (2015). A cultura do arroz. Retrieved from https://www.conab.gov.br/outras.../ item/.../2523_efd93e81ea2d9ae8f0302a6d4f9cefc6

Companhia Nacional de Abastecimento - CONAB. (2019). Acompanhamento da safra brasileira de grãos. Retrieved from: https://www.conab.gov. br/info-agro/safras/graos/boletim-da-safra-de-graos

Doran, P. M. (1998). Principios de ingeniería de los bioprocesos. Zaragoza: Acribia.

Ferreyra, M., Schvab, M., Davies, C., Gerard, L., \& Hours, R. (2012). Influence of air flow, temperature and agitation speed in the batch acetification process to obtain orange vinegar (Citrus sinensis var.W. Navel). Scientia Agropecuaria, 1, 61-65. http://dx.doi.org/10.17268/ sci.agropecu.2012.01.08.

Gomes, R. J., Borges, M. F., Rosa, M. F., Castro-Gómez, R. J. H., \& Spinosa, W. A. (2018). Acetic acid bacteria in the food industry: systematics, characteristics and applications. Food Technology and Biotechnology, 56(2), 1-31. http://dx.doi.org/10.17113/ftb.56.02.18.5593. PMid:30228790.

Gomes, T. R., Carvalho, L. E., Freitas, E. R., Nepomuceno, R. C., Ellery, E. A. C., \& Rufino, R. H. M. (2012). Effect of inclusion of rice bran in diets for piglets from 21 to 42 days of age. Archivos de Zootecnia, 61(233), 1-10.

Ho, C. W., Lazim, A. M., Fazry, S., Zaki, U. K. H. H., \& Lim, S. J. (2017). Varieties, production, composition and health benefits of vinegars: a review. Food Chemistry, 221, 1621-1630. http://dx.doi.org/10.1016/j. foodchem.2016.10.128. PMid:27979138.

Kim, S. M., \& Lim, S. T. (2016). Enhanced antioxidant activity of rice bran extract by carbohydrase treatment. Journal of Cereal Science, 68, 116-121. http://dx.doi.org/10.1016/j.jcs.2016.01.006.

Lacerda, D. B. C. L., Soares, M. S. Jr., Bassinello, P. Z., de Castro, M. V. L., Silva-Lobo, V. L., Campos, M. R. H., \& Siqueira, B. S. (2010). Qualidade de farelos de arroz cru, extrusado e parboilizado. Pesquisa Agropecuária Tropical, 40(4), 521-530.

Macías, M., Caro, I., \& Cantero, D. (1997). Optimum operating conditions in closed-system industrial acetifiers (semi-continuous operation): a study by computer simulation. Chemical Engineering Journal, 65(3), 201-207. http://dx.doi.org/10.1016/S1385-8947(97)00005-3.

Marques, F. P. P., Spinosa, W., Fernandes, K. F., Castro, C. F. S., \& Caliari, M. (2010). Quality pattern and identity of commercial fruit and vegetable vinegar (Acetic acid fermentation). Ciência e Tecnologia de Alimentos, 30(Suppl. 1), 119-126.

Nishidai, S., Nakamura, Y., Torikai, K., Yamamoto, M., Ishihara, N., Mori, H., \& Ohigashi, H. (2000). Kurosu, a traditional vinegar produced from unpolished rice, suppresses lipid peroxidation in vitro and in mouse skin. Bioscience, Biotechnology, and Biochemistry, 64(9), 1909-1914. http://dx.doi.org/10.1271/bbb.64.1909. PMid:11055395.

Rodrigues, A. P., Pereira, G. A., Tomé, P. H. F., Arruda, H. S., Eberlin, M. N., \& Pastore, G. M. (2019). Chemical composition and antioxidant activity of Monguba (Pachira aquatica) seeds. Food Research International, 121, 880-887. http://dx.doi.org/10.1016/j. foodres.2019.01.014. PMid:31108821.

Sánchez-Moreno, C. (2002). Methods used to evaluate the free radical scavenging activity in foods and biological systems. Food Science \& Technology International, 8(3), 121-137. http://dx.doi.org/10.1177/ 1082013202008003770 .

Shimoji, Y., Tamura, Y., Nakamura, Y., Nanda, K., Nishidai, S., \& Nishikawa, Y., Ishihara, N., Uenakai, K., \& Ohigashi, H. (2002). Isolation and identification of DPPH radical scavenging compounds in Kurosu (Japanese unpolished rice vinegar). Journal of Agricultural and Food Chemistry, 50(22), 6501-6503. http://dx.doi.org/10.1021/ jf020458f. PMID: 12381140.

Siepmann, F. B., Canan, C., Jesus, M. M. M., Pazuch, C. M., \& Colla, E. (2018). Release optimization of fermentable sugars from defatted rice bran for bioethanol production. Acta Scientiarum. Technology, 40(1), 1-9. http://dx.doi.org/10.4025/actascitechnol.v40i1.35000.

Silva, M. E., Torres, A. B. No., Silva, W. B., Silva, F. L. H., \& Swarnakar, R. (2007). Cashew wine vinegar production: alcoholic and acetic fermentation. Brazilian Journal of Chemical Engineering, 24(2), 163-169. http://dx.doi.org/10.1590/S0104-66322007000200001.

Spinosa, W. A., Santos, V. Jr., Galvan, D., Fiorio, J. L., \& Gomez, R. J. H. C. (2015). Vinegar rice (Oryza sativa L.) produced by a submerged fermentation process from alcoholic fermented rice. Food Science and Technology (Campinas), 35(1), 196-201. http:// dx.doi.org/10.1590/1678-457X.6605.

Tesfaye, W., Morales, M. L., García-parrilla, M. C., \& Troncoso, A. M. (2003). Optimising wine vinegar production: fermentation and ageing. Applied Biotechnology, Food Science and Policy, 1(2), 1-6.

Watanabe, M., Takahashi, M., Sasano, K., Kashiwamura, T., Ozaki, Y., Tsuiki, T., Hidaka, H., \& Kanemoto, S. (2009). Bioethanol production from rice washing drainage and rice bran. Journal of Bioscience and Bioengineering, 108(6), 524-526. http://dx.doi.org/10.1016/j. jbiosc.2009.06.014. PMid:19914587.

Watanabe, M., Yamada, C., Maeda, I., Techapun, C., Kuntiya, A., Leksawasdi, N., Seesuriyachan, P., Chaiyaso, T., Takenaka, S., Shiono, T., Nakamura, K., \& Endo, S. (2019). Evaluating of quality of rice bran protein concentrate prepared by a combination of isoelectronic precipitation and electrolyzed water treatment. Lebensmittel-Wissenschaft + Technologie, 99, 262-267. http://dx.doi. org/10.1016/j.lwt.2018.09.059. 